\title{
Lithostratigraphy and Microfacies Analysis of the Serikagni Formation Type Section, in Bara Village, Sinjar Area, NW Iraq
}

\author{
Nabil Y. Al-Banna \\ Environment and Water Resources \\ Research Center \\ Mosul University
}

(Received 3/12/2003 ; Accepted 7/4/2004)

\begin{abstract}
The type section of Serikagni Formation is studied near Bara village, northwestern Iraq. Thin section study and field observations allow the recognition of four sedimentary facies and two sedimentary cycles. Their correlation with other geological sections in Sinjar basin permits the lower cycle to be affiliated to Ibrahim Formation and the upper cycle representing Serikagni Formation.

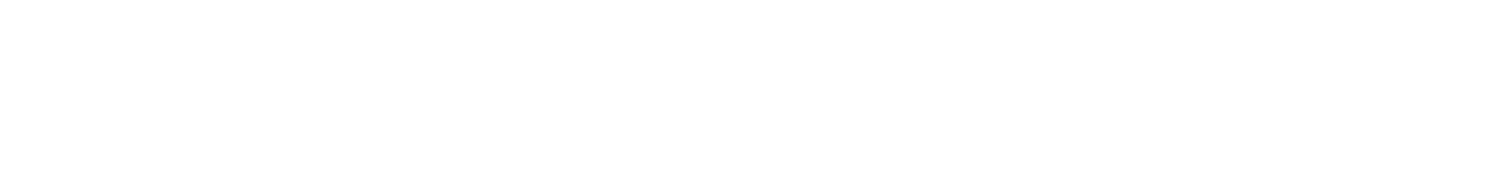

الملإص

دوس المتطع النمونجي لتكوينسريكلكني قرب قرية باروشمل غرب العراق، وقد أفرزت درلسة

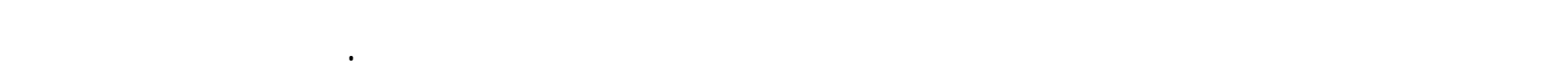

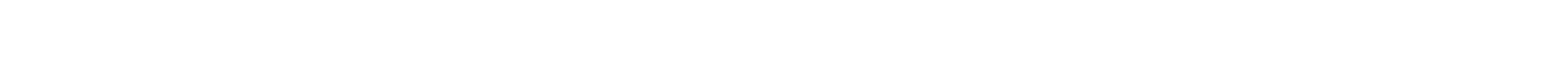
بينما تمل الدورة العليا ترسببت تكوينسرريكلكني.

\section{INTRODUCTION}

Serikagni Formation was described for the first time by Bellen (1955, in Bellen et al., 1959), where the type locality lies near Bara village in the western plunge of Sinjar anticline (Figure-1). They stated (0p.cit,p.266) that the unit ranges in lithology and faunifacies from purely globigerinal chalky limestone sediment to algal (reef) limestone. The type section embraces rocks between Oligocene rocks Probably Tarjil Fn. and Jeribe Formation (Middle Miocene) designated by Khider (1983) as Lower Miocene age. Other researchers in nearby areas assigned the extension of Serikagni Formation to early Lower Miocene (Burdigalian) Al-Eisa (1992) and Al-Banna et al. (2002). Therefore the restudy of the type section is important.
\end{abstract}


Twenty-six samples were collected from the initial type section of Serikagni Formation, which is about 145meter thick. Field description and thin section study were used to delineate the sedimentary facies and the sedimentary cycles of the type section.

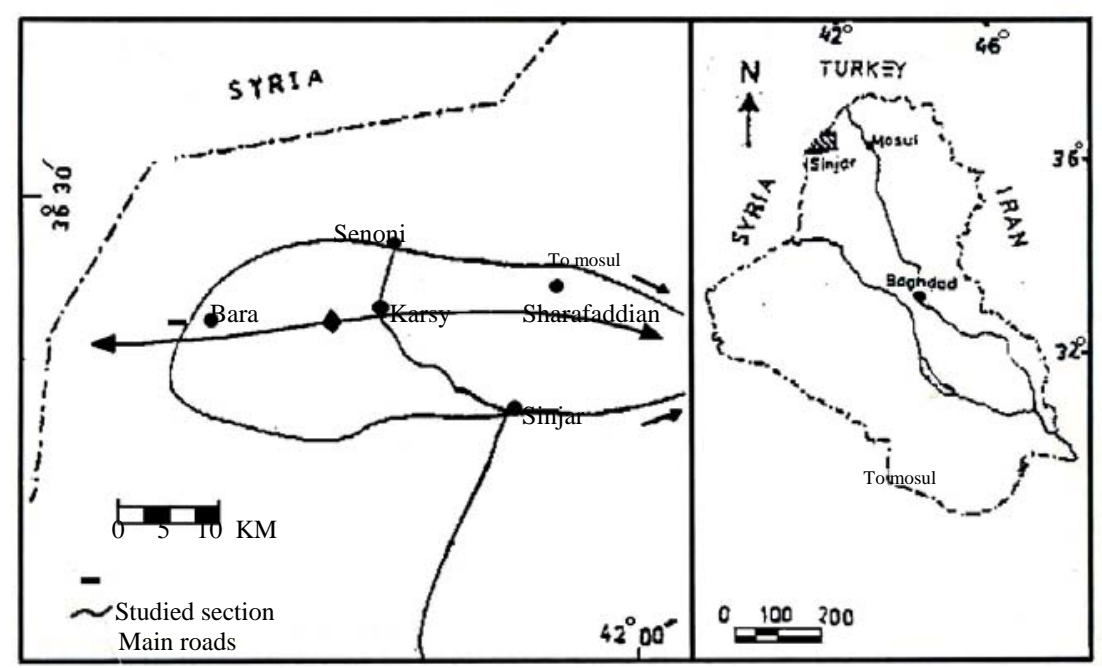

Fig. 1: Location map.

\section{Sedimentary Facies}

Generally the lithology of the studied section embraces limestone, marly limestone and intraformational conglomerate. Three microfacies and one lithofacies were recognized. The lower boundary is sharp and unconformable with the Oligocene rock (Tarjil Fn.) and the upper one is also sharp and unconformable with the Jeribe Formation, it is represented by fragmental red algal limestone microfacies.

\section{Planktic foraminiferal lime packstone microfacies (M1):}

The microfacies is composed of pale brown marly limestone with thickness ranging between 2.0-5.0 meter. The allochems percentage ranging between 50-60 \% and represented by diverse Early Miocene planktic foraminifera species belonging to Globigerinoids, Catapsydrax and Globigerina, in addition to the rare occurrence of benthic foraminifera (Plate-1). All the paleontological attributes impose an upper bathyal environment with water depth ranging between 200 - 400 m (Gibson, 1989; Berggren \& Miller, 1989) and it is a mach to SMF3 within FZ1 (Flugel, 1982). The microfacies occurs in the lower part of the section (Figure-1). 


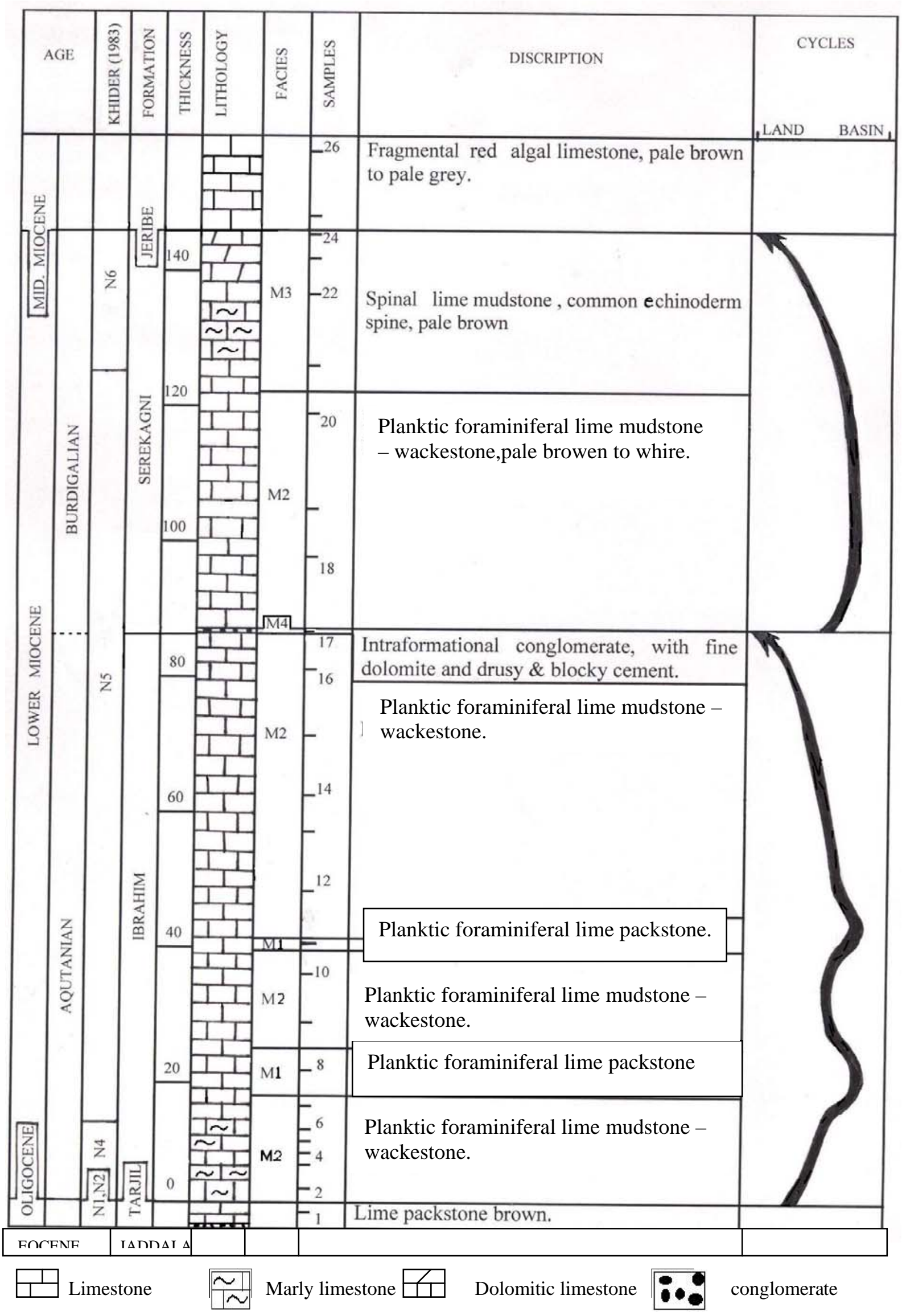


Fig. 2: Lithologic section of the studied rock ( Serikagni Fn. Type section).

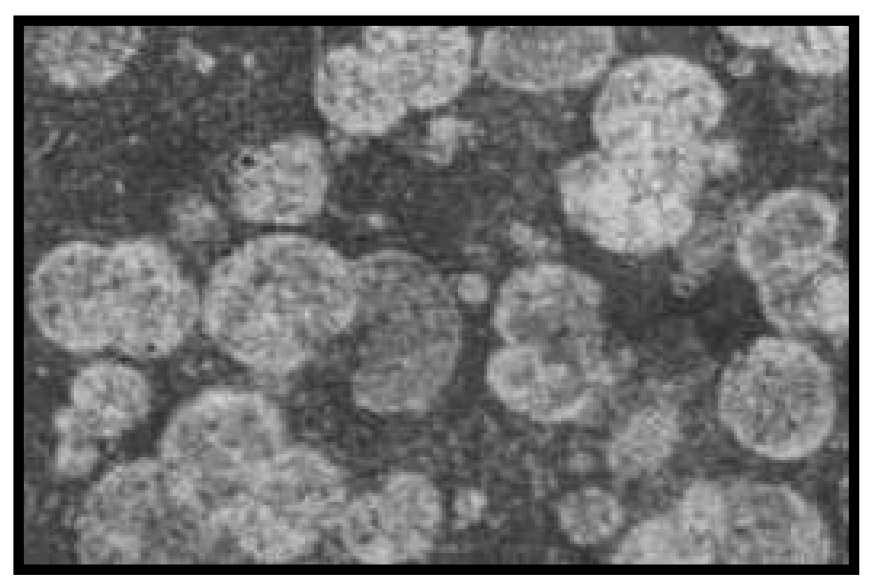

Plate 1: Planktic foraminiferal lime packstone microfacies, sample 8, X60.

\section{Planktic foraminiferal lime mudstone - wackestone microfacies (M2):}

The microfecies is characteristically pale brown limestone and marly limestone, the allochems mainly consist of planktic foraminifera, their percentage ranging between 5-30 $\%$ of the total content (Plate-2). The diversity of the fauna represented by Globigerinoides, Globigerina and Globorotalia. Rare benthic foraminifera appeared and represented by Anomalina and Cibicidoides. All the evidence of the microfacies indicate an outer shelf environment. It can be correlated with SMF8 within FZ2 (Flugel, 1982). The microfacies is occurs in the upper and lower part of the section.

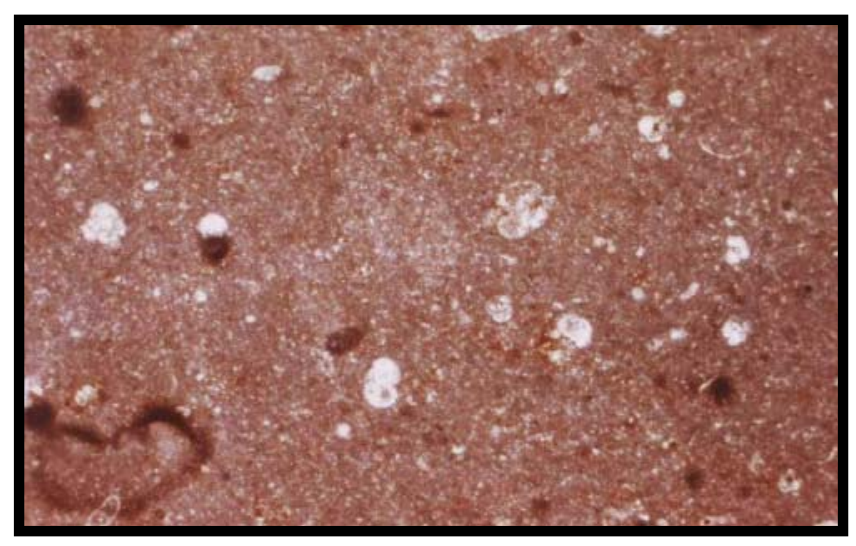

Plate 2: Lime mudstone of Planktic foraminiferal lime mudstone - wackestone microfacies, sample 15, X40.

\section{Spine-foraminiferal lime mudstone microfacies (M3):}

This microfacies occurs in the upper part of the studied section, it consists of pale brown marly limestone. Allochems attaining $10 \%$ of the total content; they consist of planktic foraminifera with rare benthic foraminifera represented by Amonalina and Cibicidoides. In addition echinoid spines are present, which indicate nearness to open 
marine outer shelf environment. It can be correlated with SMF8 within FZ2 (Flugel, 1982).

\section{Intraformational conglomerate lithofacies (M4):}

The facies consist of 0.25 meter conglomerate embracing carbonate pebbles with diameters attainting $2 \mathrm{~cm}$. Generally they are sub angular to sub rounded (pale brown) (Plate-3). The matrix is comprised of fine crystalline dolomite (brown) with drusy and blocky calcite cement filling vugs and small caverns (pale grey) (Fig.4). The facies extends laterally for hundreds meters in the field.

All the sedimentological features suggest that this type of conglomerate has accumulated in the shallowest part of the basin and probably later exposed to the surface or reaching the vadose zone.

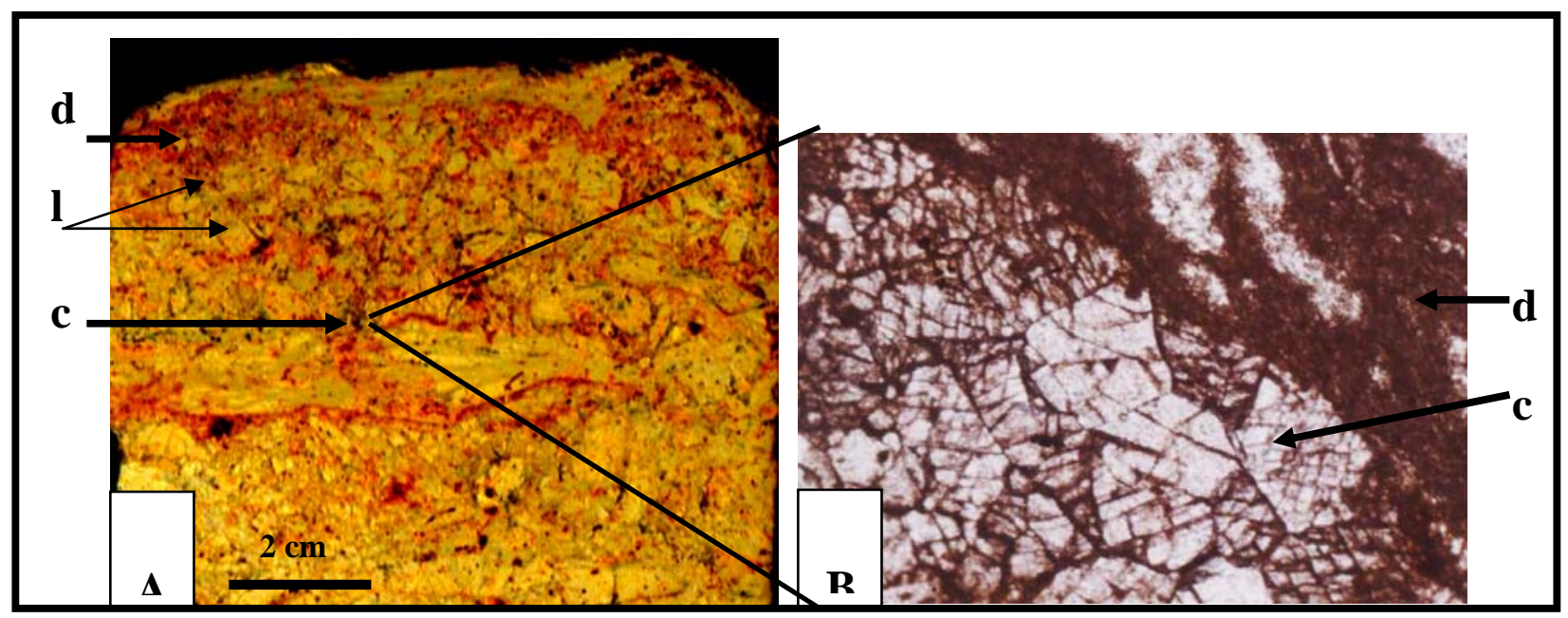

Plate 3: A. Intraformational conglomerate, B. Thin section view of (A) Sample 17, X40., c. Blocky calcite cement, d. Fine crystalline dolomite found within matrix, l. Limestone pebbles.

\section{Lower Miocene Basin:}

The microfacies study of the Serikagni Formation, in its type section elucidated the presence of two sedimentary cycles. According to Khider,(1983) the distribution of the planktic foraminifera in the type section permits the recognition of biozones which are assigned to Oligocene - Early Miocene age (the lower part is assigned to Aquitanian and the upper part to Burdigalian). In this context the previous work mentioned that the type section of the Serikagni Formation overlies the Jaddala Formation and is overlain by Jeribe Formation (Maala, 1977).

Recent study of the Oligocene-Miocene rocks in other areas promoted Ibrahim Formation to the lower Miocene age as in Kirkuk area (Al-Eisa, 1992) and in SasanShiekh Ibrahim areas (type section area of Ibrahim Formation) (Al-Banna, 1997; AlBanna et al., 2002). Their results deciphered two cycles in the Lower Miocene rocks; the 
first cycle included Ibrahim, Azkand, Anah and Hamrin Formations while the second cycle is represented by Serikagni, Euphrates and Dhiban Formations.

The Lower Miocene in Sinjar basin shows wide distribution, it extends from Butmah and Rafan areas in the eastern margin (Al-Banna, 1997) to the western plunge of Sinjar anticline and probably inter the Syria boarder. According to Al-Banna, (1997) the lagoonal facies of the first cycle (Anah Formation) found in Butmah and Rafan areas, while the reefal facies (Azkand Formation) shows north-south elongation between Sasan and Butmah areas. The deep marine equivalent (Ibrahim Formation) is distributed from Sheikh Ibrahim to Sinjar area, whereas regressive episode of the first cycle is represented by Hamrin Formation (Al-Banna \& Amin, 2000). In the second cycle Euphrates Formation of lagoonal facies was distributed in Butmah and Rafan areas, while the oolitic bars of the same Formation is present in Sasan and Sheikh Ibrahim areas (Al-Banna, et al., 2000). Their deep marine equivalent rocks (Serikagni Formation) extends from Sheikh Ibrahim and Sasan areas to Sinjar area, the regressive phase of the second cycle is represented by Dhiban Formation.

According to the above mentioned information and lateral correlation of the type section (Figure-3); a bipartite division of this two formations is plausible. This manifested by the unconformable discontinuity surface displayed as intraformational conglomerate facies assigned to Hamrin formation. The lower part is designated as Ibrahim Formation while the upper part restored the qualification of Serikagni Formation; moreover the lower five meters of the section is of Oligocene age and probably representing the Tarjil Formation.

The outcome of this study dictates the separation of previously commingled Ibraham-serikagni Formations of the initial type section (near Bara village) in two formations as its implicitly considered in the geological column of Iraq, and it accords with the international stratigraphic code of nomenclature (Murphy and Salvador, 1999). Therefore, it follows that the thickness of Serekagni Fn. (in the type section) should be reduce to $60 \mathrm{~m}$ instead of $145 \mathrm{~m}$, where the lower $85 \mathrm{~m}$ is affiliated to Ibrahim Fn. 
Lithostratigraphy and Microfacies Analisysis ... 


\section{REFERENCES}

Abawi,T. S. and Maroof, R. A., 1988. Planktonic foraminiferal and biostratigraphy of the Oligocene Ibrahim Formation, Sinjar area, Northwestern Iraq-N.Jb.Geol. Palaont. Mh. 1987, (7), pp.391-402: Suttgart.

Abawi, T. S. and Maroof, R. A., 1992. Planktonic foraminiferal and biostratigraphy of the Oligocene Serikagni Formation, Sinjar area, Northwestern Iraq. -N.Jb.Geol. Palaont. Mh. 1992, (12), pp. 709-720: Suttgart.

Al-Banna, N. Y., 1997. Sedimentological and stratigraphical study of the Upper Oligocene-Middle Miocene, west Mosul. (Unpubl.) Ph.D. Thesis, Uni. of Mosul. Iraq. $177 \mathrm{p}$.

Al-Banna, N. Y. and Amin, M. A., 2000. Sedimentology of (Hamrin Formation ?) in Sasan and Sheikh Ibrahim areas. The $5^{\text {th }}$ Scientific Conference of SRC, pp.275-282.

Al-Banna,N.Y.; Al-Hashimi,W.S. and Amin, M. A., 2000. The distinguish between Jeribe and Euphrates Formations,West Mosul. Raf. Jour.Sci.,11,(2),pp. 68 -79 .

Al-Banna, N. Y., 2002. Microfacies analysis of Oligocene Formation in Butmah and Rafan area, Northwest Iraq. Raf. Jour. Sci., in press.

Al-Banna, N. Y. and Al-Mutwali, M. M., 2002. Sedimentary cycles and microfacies analysis of Lower Miocene Formation in Sinjar and Sharafaddin areas NW Iraq. Raf. Jour. Sci., Impress.

Al-Banna, N. Y., Amin, M. A. and Al-Hashimi W.S., 2002. Oligocene -Miocene boundary in Sheikh Ibrahim and Sasan areas,NW Iraq. Iraqi Journal of Earth Sciences, 2, (2), pp. 37-47.

Al- Eisa, M. E., 1992. The subdepositional cycles of early Miocene in Kirkuk field, North Iraq. Jour., Geol., Soc., Iraq. 25, (1), pp. 41-58.

Al-Mutwali, M. M. and Al-Banna, N. Y., 2002. Planktic foraminiferal biostratigraphy of the Oligocene Palani and Tarjil Formation, Sinjar area Northwestern Iraq. Raf. Jour. Sci.,13, (4), pp. 70-80.

Bellen, R. C. Van, Dunnington, H. V. and Wetzel, R., 1959. Lexique Stratigraphique International Asie, Fascicule 10a, Iraq-Paris Center National de Ia Recherche Scientique, 333p.

Berggren, W. A. and Miller, K. G., 1989. Cenozoic bathyal and abyssal calcareous benthic foraminiferal zonation. Micropalentology. 35, (4), pp. 308-320.

Flugel, E., 1982. Microfacies Analysis of Limestone Translated by Chrcsteusen , K., Springer-Varlag, Berlin, 633p.

Gibson, T. G., 1989. Planktonic benthonic foraminiferal ratios: modern patterns and Tertiary application. Marine Micropaleontology. 15, pp. 29-52.

Khider, K. K., 1983. Biostratigraphy of Serikagni Formation. (Unpubl.) M.Sc. Thesis, Uni. of Baghdad.Iraq. 100p.

Maala, K. A., 1977. Geology of Sinjar area part 1, No.860. S.O.M. (Unpupl. Report) Baghdad. 
Lithostratigraphy and Microfacies Analisysis ...

Murphy, M. A., and Salvador, A., 1999. International subcommission on stratigraphic classification of IUGS, International commission on stratigraphy, (International stratigraphic guide - An abridged version). Episodes 22, (4), pp. 255-270. 